\title{
THE IMPORTANCE OF FINANCIAL MANAGEMENT PRINCIPLES IN THE STATE BUDGET EXECUTION
}

\author{
Yuriy HOLYNSKYY ${ }^{1}$ \\ ${ }^{1}$ Ph.D. in Finance, Associate Professor, Ivan Franko National University \\ of Lviv, Faculty of Financial Management and Business, Kopernyka St 3, 79000, \\ Lviv, Ukraine, Tel.: +380978568404, Email: yuriy.holynskyy@lnu.edu.ua
}

\begin{abstract}
In the structure of the financial system of each state, one of the most important places is given to the budget, which characterizes the degree of development of budget relations that arise between government bodies and economic entities in the process of distributing gross domestic product. The budget as an instrument of macroeconomic regulation has an impact on the development of social sectors, the functioning and modernization of national defense and law enforcement activities, the development of national economic sectors and the welfare of the society.

At the same time, the implementation of budgeted activities of supporting the sectors of the national economy and other activities depends not only on their consideration in drawing up the budget, but also on the quality of its execution.

In this paper, author determines the possibilities of using the financial management principles in the public sector during all stages of state budget execution.
\end{abstract}

Keywords: budget execution; financial management; public finance; New Public Management.

JEL Classification: $\mathrm{H}_{72}$

\section{Introduction}

The state budget has paramount importance for all areas of public life. In the process of execution of various government functions, public authorities implement the necessary state regulation in the sectors of the national economy and social sphere through the financing and redistribution of funds provided for these purposes in the budget and in the main areas of budgetary policy. At the same time, 


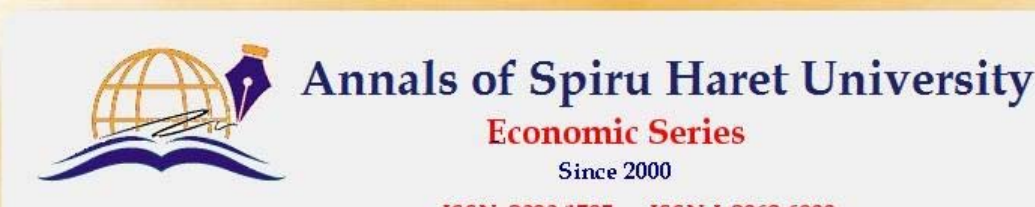

ISSN: 2393-1795 ISSN-L:2068-6900

Issue 4/2017

the quality and timeliness of the implementation of these public functions by state authorities depends on the organization of the execution of the state budget.

The importance of researching the problem of state budget execution is also in its ability to influence the implementation of the priorities set by state policy while simultaneously meeting all previously established obligations to the society, which is characteristic of a socially-oriented state.

The ongoing changes in the management of public finances imply the active implementation of fundamentally new tools for budget planning and financing, which necessitates the improvement of stages of the budget process, including the stage of state budget execution.

Compared with other stages of the budget process, budget execution covers a significant time period and involves the interaction and participation of a large number of business entities and public authorities.

Almost like any complex fact, the system of budget execution can be considered in functional and organizational aspects. At the same time, in the organizational aspect, the system of budget execution is represented by a set of entities participating in the framework of their competence.

The specifics of the organizational aspect of the state budget execution imply the need to analyze the arising relations between various subjects of economic relations and the authorities regarding the formation of budget revenues and expenditures. The study of the organizational aspect makes it possible to analyze the content and specificity of the relations between certain groups of participants and non-participants in the budget process from a position of specific types of revenues, the budget deficit financing sources and forms of budget expenditures inherent to each of them.

The functional aspect allows us to consider the budget execution system from the standpoint of the individual components of the budget execution process, namely: the implementation of the budget by revenue, expenditure and sources of financing the budget deficit. This aspect of researching the content of individual components of the budget execution allows to obtain a holistic view of the nature, volume and structure of the current expenditures, received and used sources of financing the budget deficit, as well as the ratio and receipt of the corresponding revenues of the state budget in comparison with their projected values. Thus, the functional aspect allows getting an idea of the reliability of planning budget allocations and sources of financing the budget deficit, as well as the reliability of forecasting the revenues of the state budget. 


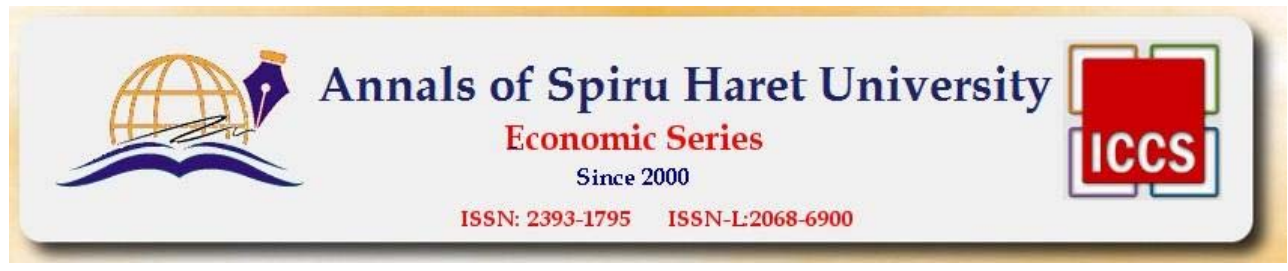

Issue 4/2017

These aspects, by their nature, are necessary because each of them leads to the conclusion about the quality of the organization of the state budget execution for the relevant participants of the budget process, as well as about the results of providing expenses determined by the budget law.

In connection with the above, researching the execution of the state budget and improving the instruments used for the goals and objectives of implementing program-targeted planning and financing are relevant and necessary.

\section{Literature review}

Definitely, the main scientific research that had influence on writing this paper is Reinventing Government: How the Entrepreneurial Spirit Is Transforming the Public Sector by D.E. Osborne and T. Gaebler [Osborne \& Gaebler, 1993]. In that book, the authors define how, adjusted from the private sector, the operating principles can improve the government functions, with a large amount of examples.

Another important paper is "based on general review of literature such as relevant books, journals, articles and newspapers, attempts to pinpoint the emergence, principles and criticisms of New Public Management considering its theoretical aspects" [Kalimullah et al., 2003].

There is also an interesting issue about the connection between the private management and the public sector in the article written by Liebman and Mahoney - "many organizations have budgets that expire at the end of the fiscal year. In the United States, most budget authority provided to federal government agencies for discretionary spending requires the agencies to obligate funds by the end of the fiscal year or return the funds to the Treasury; state and municipal agencies typically face similar constraints” [Liebman \& Mahoney, 2017].

The importance of transparency of budget execution is described in [Ríos et al., 2016]. Authors in "this article attempt to evaluate the role the legislative budgetary oversight plays in enhancing budget transparency”.

\section{Results and discussion}

Transformation of the directions of economic development associated with the transition to innovative approaches urgently requires changes in the organization and functioning of the entire public administration sector, including modernization and implementation of new conceptual approaches to the management of public finances.

In this regard, many countries are actively pursuing reforms in public finances aimed at increasing the effectiveness and transparency of the financial system, 


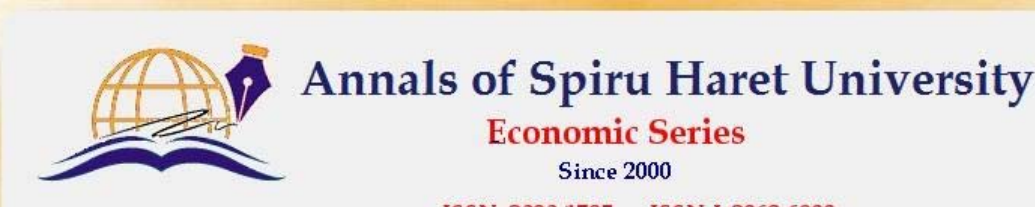

ISSN: 2393-1795 ISSN-L:2068-6900

Issue 4/2017

strengthening the responsibility of government authorities for the consequences of their managerial decisions based on the managerial model of public administration.

At the present time, management tools in the public sector, including implementation of measures based on the results of public management, are not widely used in developing countries.

Thus, in the context of the transition from cost management to the concept of results management, the role of assessing the quality of financial management in the public administration, including assessing the quality of financial management of public authorities involved in the execution of the state budget, is growing.

The idea of introducing the concept of public management in the public sector for foreign countries is not new, since as early as in the $20^{\text {th }}$ century separate attempts were made to bring the processes of increasing the efficiency of budget expenditures closer to the growth of their effectiveness in business. The solution of this problem was also researched in the implementation of the bases for developing the effectiveness of the activities of state structures and organizations and shifting the emphasis of management from the costs of results.

In the 1930s, the term "performance budgeting" arose in the scientific community, which later gave rise to the formation of a new term "New Public Management", which was characterized by D. Osborne and T. Gabler in the scientific work Reinventing Government: How the Entrepreneurial Spirit Is Transforming the Public Sector [Osborne \& Gaebler, 1993] as being a set of modern approaches to the management of the new sector, which became the core of intellectual thought in the field of public finance.

Thus, the need to use a managerial approach to the management of public finances is largely due to the increasing role of the state in the economy and the social sphere and in terms of the shift from the focus on the volume of intervention to its efficiency and effectiveness.

The essence of this process was very accurately described by R. Lee: “...whereas traditional budgeting, oriented on budgetary resources, is primarily focused on the amount of budget expenditures, the new format shifts this emphasis to results from budget expenditures" [Lee et al., 2012].

In general, analyzing different points of view on this concept, it should be noted that the scientific and methodological justification of the state's financial management system is capable of becoming a reliable basis for implementing strategic guidelines, including the economic implementation of growth in developing countries. 


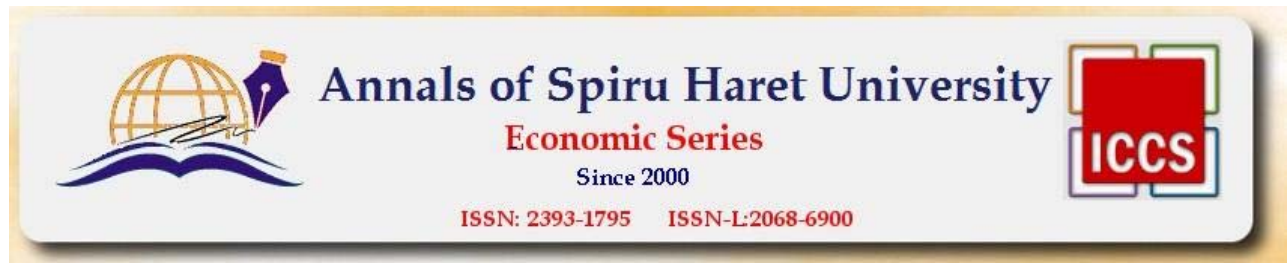

Issue 4/2017

At the same time, it should be noted that the solution of this task is impossible without the creation of a complete and effective system of public financial management capable of ensuring a macroeconomic balance, increasing the effectiveness and transparency of the management of public financial resources.

Based on the above information and taking into account the classical theory of financial management, we will try to identify the main elements of the public financial management system that will be applicable to the budget system of developing countries, including the execution of the state budget.

Considering the management of public finances through the prism of the principles of financial management, it can be noted that it is a set of interrelated and interdependent elements, namely: the organization of financial resources management, financial forecasting and planning, financial regulation, financial control.

The main objective of the public financial management in managing the system of state budget execution is to maximize budget revenues to improve the quality of public services for the society through the timely and complete financial provision of the budgetary spending.

Thus, it should be noted that the public financial management managing the system of state budget's execution is a complex of subsystems aimed at achieving the main goal by means of the key elements of this system. These subsystems provide the management of state budget revenues, expenditures and sources of budget deficit financing, in which certain procedures, processes and technologies are designed to minimize budget risks and losses, the implementation of financial control over budget implementation by applying a set of financial leverage to ensure the quality of public services for the society.

It is also important to note the existing conditions, which contribute to the need to implement public financial management principles in the execution of the state budget. One of the main conditions, first of all, is the results-oriented budgeting.

The main goal, in turn, of the results-oriented budgeting is the integration of the budgetary allocations' provision with the results of the activities of the budgetary planning subjects.

The research conducted by the author in the field of results-oriented budgeting showed that the process of modernizing the public financial management in the global community is ambiguously and has both supporters and opponents among representatives of science and practice. The systematization of the opinions of supporters and opponents of results-oriented budgeting can be presented in the following form. 
Issue 4/2017

Opinions of those supporting the New Public Management ideology:

- disadvantages of traditional budget financing lie in the fact that it is aimed at budgeting costs, rather than the results of the activities of public authorities and public organizations;

- the system of budget financing does not allow to react quickly to new needs and opportunities, fixing in the structure of expenses the decisions of "yesterday", corrected by a biased and sufficiently defective method of increment;

- the budget system makes budgetary planning complex and opaque, and transparency disappears as the main characteristic of the budget.

Opinions of those opposing the New Public Management ideology:

Performance management systems, first of all, are intended for industrial and production activities of a cyclic nature. Most of the activities of public authorities are multi-purpose, and many political tasks cannot be quantified.

The causal relationship between activity and its outcome in the public administration sector is generally weak. There is a long period of time between the process of activity and the receipt of the planned results.

Most performance indicators are subjective, and their evaluation is associated with high costs, so that results-based management methods cannot be completely objective.

The brief overview of the budgeting elements that have been formed so far in terms of the direction of budget planning has made it possible to identify a number of key areas.

First, they include the characteristics of the goals, objectives and performance indicators of the main administrators of budgetary funds, as reflected in the annual reports on the results and main activities of the subjects of budget planning.

The indicators used in them are divided into two groups: funds;

- formed directly from the activities of the main administrators of budgetary

- formed based on the operation of the subordinate network.

Secondly, the transition to the organization of public services and the development of administrative regulations, including:

- general provisions;

- the standard of provision;

- the composition, sequence and timing of the implementation of administrative procedures (actions);

- requirements for their implementation; 


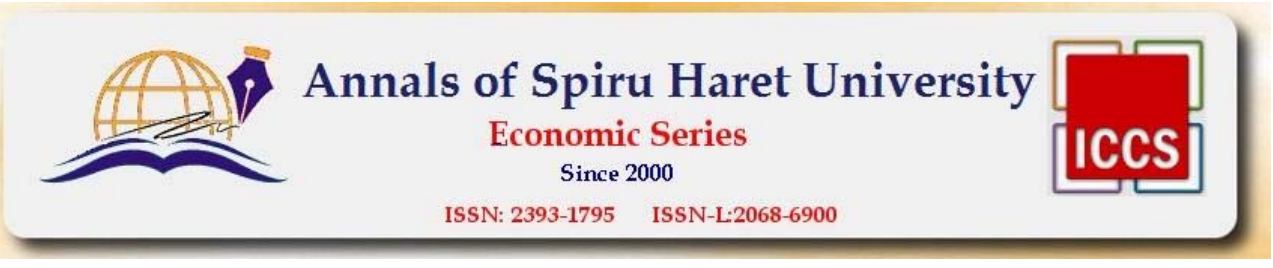

Issue 4/2017

- forms of control over the implementation of administrative regulations;

- pre-judicial (extrajudicial) procedure for appealing decisions and actions (inaction) of the body that provides public services and their officials.

In addition, basic and departmental (sectoral) lists of public services are being formed in developing countries at present time.

The basic ones are approved by the state bodies of executive power, which carry out the functions of public policy development and legal regulation in the established sphere of activity, and departmental ones - by bodies responsible for the functions of state autonomous institutions, as well as the main administrator of budgetary funds.

Thirdly, the specification of the provided public services makes it possible to determine their value. It should be noted that the normative costs for a particular budget service are allowed to be calculated for each institution separately and for the group - on average, or taking into account corrective factors that are correlated with the specifics of providing the services (provision of engineering infrastructure, the status of the municipality, etc.).

Fourthly, the transition of determining the amount of funding from the calculation of the needed cost for the functioning of public sector institutions to planning the cost of performing public tasks for the providing of public services.

Common in these types of public tasks are:

- provision on early termination of the performance of the state task;

- the order of control over its execution;

- the form of the report on performance and its terms.

The results-based budgeting tools and, at the same time, the innovations in the public sector have created conditions that allow the development of the financial mechanism in the management of state budget system. In addition, the public financial management is also aimed at improving the efficiency and effectiveness of the implementation of fiscal policy.

Based on the above, we can form a model of the management system's results at all stages of the budget process, considered from the standpoint of the principles of financial management and including the corresponding four phases presented in Figure no. 1.

It should be noted that monitoring in this case is an end-to-end element and is present in each phase, thus its leading role should occur in the monitoring phase of the budget execution. 
Issue 4/2017

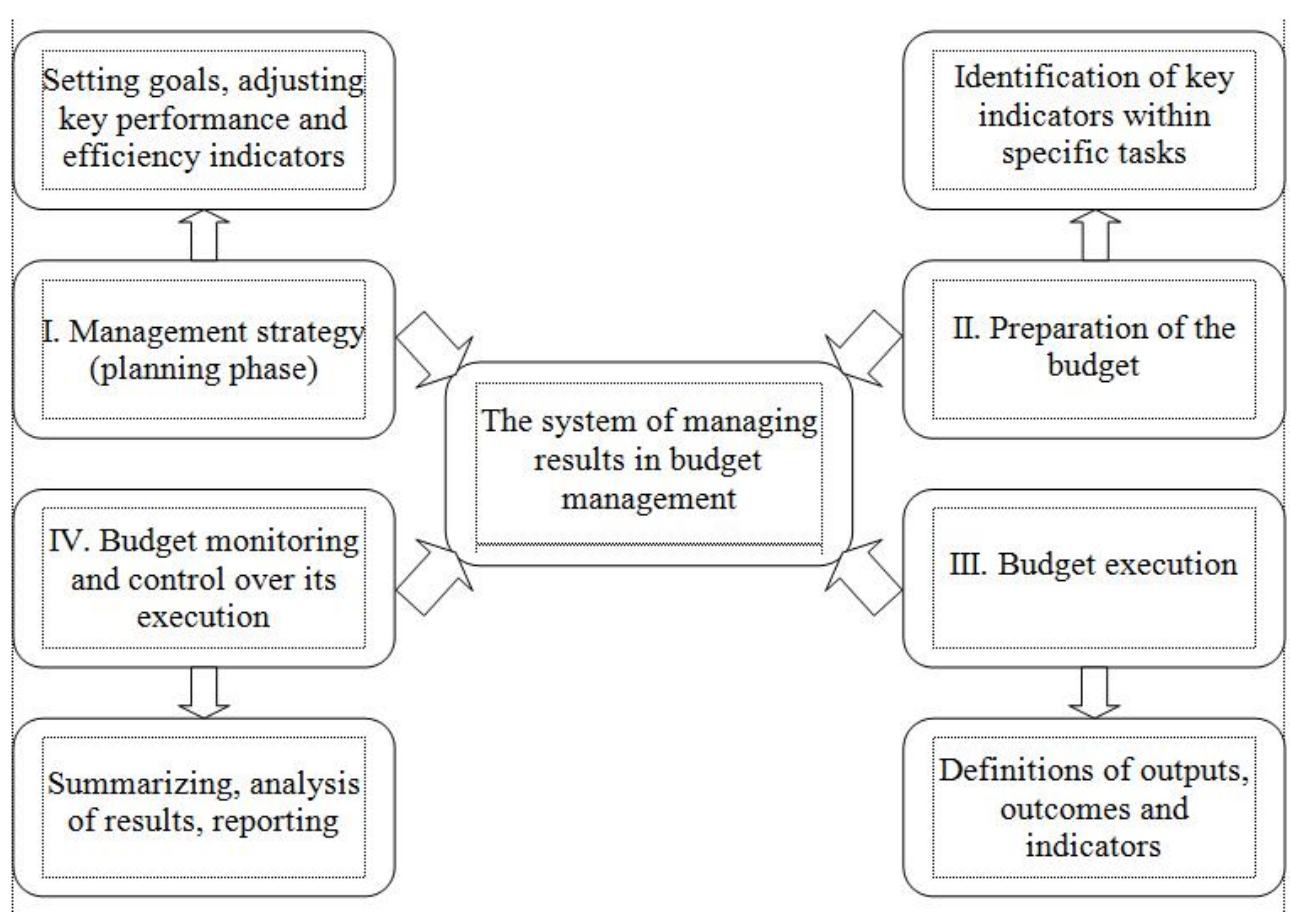

Figure no. 1. The system of managing results in budget management

Source: personal contribution

In the strategic planning of the activities, predetermined by the program-target method, indicators are developed to determine the results and the effectiveness that are expected in 3-5 years, and other indicators that are directly related to the development of the budget for the next year (program and non-program part of it).

Also it should be noted that results-based budgeting is a different budget management paradigm, which implies fundamental changes in approaches to all components of the management system: planning, goal setting, monitoring, etc. Simultaneously, results-based budgeting is regarded as the budget management paradigm providing a radical change in approaches to the structure of the budgetary process, i.e. to the budget process: drawing up, parliament discussion, execution of budgets and budgetary control. Lack of such an understanding can lead to the fact that the results-oriented budgeting tool can be implemented as a formal project. 


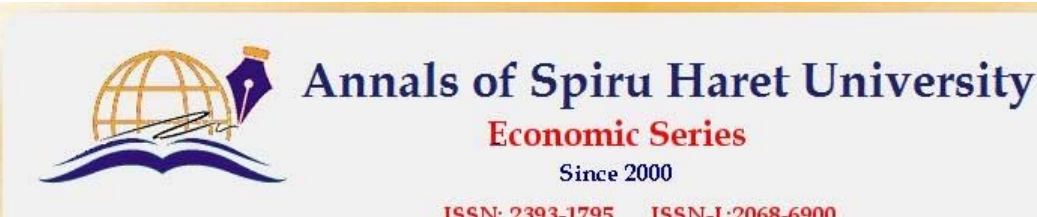

ISSN: 2393-1795 ISSN-I -2068-6900

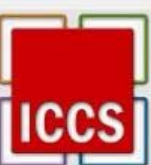

Issue 4/2017

During the implementing principles and elements of results-based budgeting in practice, the possibility of establishing performance indicators for most government services provided by public authorities and state institutions should be used. The experience of developing countries in the development of results-based budgeting demonstrates a significant arsenal of indicators for assessing public services developed both at the state level and at the level of its regions and municipalities, that have a clearly defined professional reference point and are able to overcome the system of limitations identified by opponents of the New Public Management theory.

\section{Conclusions}

The process of state budget execution not only has an impact on the timely and fully transfer of the incomes to the budget, but also on improving the efficiency of using budget funds, which, in turn, are formed to implement the state budget policy and ensure the development of budget and management tools of public administration.

Execution of the state budget is the most important stage of the budgetary process in developing countries, within the framework of which the planned tasks and plans are being implemented.

Financial (budgetary) management is a process of managing the formation, distribution and use of public resources and optimizing the use of financial resources in the interests of socio-economic development of individual regions and the country as a whole. It is aimed at solving the following main interrelated tasks: ensuring high financial sustainability of legal entities in the process of their social and economic development and optimizing cash flows on the territory of public legal entities.

Future researches can be concerned with further specification of financial instruments, which are used in the private sector, but also can be implemented to the management of state budget execution.

\section{References}

1. Kalimullah, Nazmul Ahsan, Ashraf Alam, Kabir M. \& Nour, Ashaduzzaman, "New Public Management: Emergence and Principles,” Bup Journal 1(1), 2012: 1-22.

2. Lee Jr, R.D., Johnson, R.W. \& Joyce, P.G., Public Budgeting Systems (Jones \& Bartlett Publishers, 2012).

3. Liebman, Jeffrey B. \& Mahoney, Neale, "Do Expiring Budgets Lead to Wasteful Year- 
Issue 4/2017

End Spending? Evidence from Federal Procurement,” American Economic Review 107.11, 2017: 3510-3549.

4. Noordegraaf, Mirko, Public Management: Performance, Professionalism and Politics (Palgrave Macmillan, 2015).

5. Osborne, David \& Ted Gaebler, Reinventing Government: How the Entrepreneurial Spirit Is Transforming the Public Sector (New York: Penguin, 1993).

6. Ríos, Ana-María, Bastida, Francisco \& Benito, Bernardino, "Budget Transparency and Legislative Budgetary Oversight: An International Approach,” The American Review of Public Administration 46.5, 2016: 546-568. 